\title{
Prevalence of Micro-organisms in Flies and Meat cuts in Uyo Abattoir, Akwa Ibom State.
}

\author{
A. U. ENO-OBONG, A. Y. ITAH and C. O. OBUN
}

(Reccived 15 April 2003; Revision Accepted 9 September 2003)

\section{ABSTRACT}

A total of 100 samples, 50 each of fresh meat cuts and flies were aseptically collected from Iba-Oku Abattoir in Uyo, Akwa Ibom State periodically and processed for quantitative and qualitative microbiological analysis using cultural procedures. Results of quantitative analysis revealed microbiological load of flies ranging from $1.8( \pm 0.02) X$ $10^{6}$ to $1.83( \pm 0.33) \times 10^{6} \mathrm{cfu} / \mathrm{g}^{-1}$ while that of meat cuts ranged from $1.2( \pm 0.02) \times 10^{5}$ to $1.25( \pm 0.33) \times 10^{6} \mathrm{cfu} / \mathrm{g}^{-1}$. The viable plate count (VPC) of Micro-organisms on flies was significantly $(P<0.05)$ higher in all the weeks of analysis. Qualitative evaluation of bacterial flora of the meat cuts and flies revealed Staphylococus aureus as the most predominant organism, $48 \%$ and $50 \%$ respectively while Proteus was the least with $12 \%$ and $14 \%$ incidence in meat cuts and flies respectively. Apart from known mycotoxin producing Aspergillus and Penicillium species encountered in this work, the occurrence of Stapylococcus aureus, $E$. coli, Bacillus cereus, Staphylococcus epidermidis, Micrococcus roseus, Bacillus subtilis, Streptococcus, Klebsiella, Pseudomonas, and Salmonella species is indicative of gross contamination and constitute potential health hazard to consumers. Continuous microbiological surveillance of abattoirs is recommended to avert imminent danger of food borne intoxications. The public health significance of these findings are discussed in the paper.

\section{KEYWORDS: Microbial, Contamination, Meat cuts, Flies, Abattoir.}

\section{INTRODUCTION}

Enteric pathogens are responsible for intestinal infections like bacillary dysentery, typhoid fever and bacterial food poisoning. Flies are insect vectors of disease and are responsible for the transmission of enteric organism through contamination of water and food materials. They spread disease by collecting micro organisms from human excreta, rotten material, sewage and manure and distributing them along their path, transmitting several infectious diseases like salmonellosis, cholera, typhoid fever and amoebiasis (Greenberg and Bornstein, 1973; Awan, 1983; Frazier and Westhoff, 1978).

Sabestine and Aye (1989) in their studies on houseflies in Tamue, Yangon and Myamman reported the occurrence of Escherichia coli, Vibrio cholerae, Shigella species in varying proportions. Flies carrying these organisms can deposit them on meat sold in open places like the abattoir and open markets. This leads to contamination of meat and other foods particularly by aerobic micro-organisms as earlier reported (Frazier and WestHoff, 1978). Porke (1971) reported the mean bacterial count of beef as $2.6 \times 10^{4}, 1.4 \times 10^{6}$ and $1.5 \times$ $10^{7} \mathrm{cfu} / \mathrm{g}$ at butchers home and market respectively. Many food poisoning outbreaks due to salmonella in meat have been reported in Nigeria (Ndifon et al, 1997). Greenberg and Bornstein (1973) isolated Pseudomonas, Proteus and Streptococcus sp., Staphyloccocus aureus. Staphylococcus epidermidis, Salmonella sp. and Clostridium perfringens from goat meat marketed in Mexico. Greenberg and Bornstein (1973) in their studies on flies, rats and livestock in Mexican slaughter house, isolated 12 Salmonella sp. from 10 flies and 4 from slaughtered animals and local rats.

The main objective of this work is to assess the sanitary condition of Uyo abattoir (lba - Oku) by determination of microbial load in fly pools, meat cuts and identification of microbial contaminants that may constitute potential health hazard to consumers.

\section{MATERIALS AND METHODS}

A total of 100 samples, 50 each of fresh meat cuts and flies were randomly collected from the abattoir at Iba Oku, Akwa lbom State for a period of two months in the early hours of the day. The flies that perched on this meat cuts were caught with the help of a quadrate. The samples were analyzed for microbial load and the organisms characterized and identified using the taxonomic scheme of Cowan (1978) and Holt et al (1994) for bacteria and Talbot (1978) for fungi.

$1 \mathrm{ml}$ of aliquot from $10^{-5}$ dilution of each sample was aseptically transferred to sterile Petri dishes in triplicates. $10-15 \mathrm{ml}$ of Molten plate count agar (Oxoid Ltd, England) were poured into one set of triplicate plates containing the inoculum while molten Potato Dextrose agar (Oxoid Ltd, England) was dispensed into another set of triplicate plates (Containing the inoculum) for bacterial and fungal enumeration respectively. All the plates were gently swirled in the usual way and allowed to set on the bench. They were then incubated at $37^{\circ} \mathrm{C}$ for 24 hours for enumeration of bacteria and at 
Table 1:

Triplicate plate count Average of Bacteria isolated from nueat cuts and flies in Uyo Abattoir (lba-Oku).

\begin{tabular}{|l|l|l|}
\hline Weeks & Meat cuts (cfu/g) & Flies (ciu/g) \\
\hline 1 & $1.20( \pm 0.18) \times 10^{5}$ & $1.81( \pm 0.01) \times 10^{6}$ \\
\hline 2 & $1.25( \pm 0.33) \times 10^{6}$ & $1.80( \pm 0.02) \times 10^{6}$ \\
\hline 3. & $1.23( \pm 0.19) \times 10^{5}$ & $1.82( \pm 0.33) \times 10^{5}$ \\
\hline 4. & $1.24( \pm 0.33) \times 10^{6}$ & $1.81( \pm 0.28) \times 10^{6}$ \\
\hline 5. & $1.25( \pm 0.33) \times 10^{6}$ & $1.83( \pm 0.33) \times 10^{5}$ \\
\hline 6. & $1.24 \pm 0.18) \times 10^{6}$ & $1.81( \pm 0.33) \times 10^{6}$ \\
\hline 7. & $1.25( \pm 0.32) \times 10^{5}$ & $1.80( \pm 0.28) \times 10^{5}$ \\
\hline 8. & $1.25 \pm 0.33) \times 10^{6}$ & $1.82( \pm 0.30) \times 10^{6}$ \\
\hline
\end{tabular}

$( \pm)$ : Standard error.

Results indicate mean of three replicates:

room temperature of $26{ }^{\circ} \mathrm{C}$ for $3-5$ days for fungal isolation. Plates having $30-300$ colonies were counted. Representative colonies were purified by repeated subculture on fresh plates using the streak plating techniques. Pure cultures of bacteria were preserved in slants of nutrient agar by refrigeration at $7^{\circ} \mathrm{C}$ while fungal isolates were preserved in slants of corn meal agar at room temperature. Pure isolates were characterized and identified using standard procedures earlier described.

The test criteria included Gram's reaction, catalase test, oxidase test, carbohydrate fermentation, methyl red test (Fawole and Oso (1988), and IMViC tests (Cruickshank et al, 1975). Their identity was further confir:ned on selective media by surface plating.

Data collected were subjected to analysis of variance according to Snedecor and Cochran (1978).

\section{RESULT AND DISCUSSION}

The microbiological analysis of 50 meat cuts and 50 flies from Uyo Abattoir have revealed varying degrees of contamination. Results show that the mean viable count was lower in meat cuts $\left(1.25 \pm(0.33) \times 10^{6}\right.$ cfulg) and significantly $(P<0.05)$ higher in flies $(1.81$ ( $t$ 0.33) $\left.\times 10^{6} \mathrm{cfu} / \mathrm{g}\right)$ (Table l): All the meat cuts from animals slaughtered in Uyo abattoir had viable micro organisms of public health concern, the number however depends on the level of contamination of the meat during handling process as they are usually washed with contaminated water and thereafter exposed in the open. When flies feed on exposed faeces, they may perch on the meat thereby contaminating them.

According to the ICMSF (1980), counts of $10^{5}$ cfu/g and above in foods are considered hazardous to the public. Such foods are not fit for human consumption. Such high counts of viable microorganisms obtained in this work could be attributed to the use of contaminated wash water, insanitary conditions of the emviroment and frequent exposure of the meat to airborne microorganisms as they are displayed often by the roadside.

Table 2 shows the incidence of bacterial isolates from meat cuts and flies. It was observed that most of the micro organisms isolated from flies were also isolated from meat cuts thus implicating flies as the commonest domestic insects that carry the organisms because of their dirty habit according to Awan (1083). Staphylococous aureus was found to be the most frequently occurring organism in meat at and flies probably because they are abundant on the skin and nostrils of the butchers and sellers who often disseminate them. $48 \%$ and $50 \%$ of isolates were identified as Staphylococcus aureus while Proteus $s p$ had $12 \%$ and $16 \%$ respectively. The results of the prevalence of Staphylococcus aureus, Salmonella sp $(30 \%$ and $10 \%)$, Staphylococcus epidermidis (26\% and $34 \%)$, Bacillus sp $(40 \%)$, Escherichia coli $(40 \%$ and $46 \%$ ) are shown in Table 2 . This shows the prevalent rate of contamination by the organisms as a result of exposure of the meat to unhygienic abattoir environment. The organisms isolated in this work have either been implicated in food poisoning out breaks or are potential agents of food borne infections as they produce enterotoxins (Itah and Opara, $1994 \mathrm{a}$ and b; Itah and Opara, 1997 and Itah, 1997 and 1998). The presence of $E$. coli in food is unacceptable at any level as they are strong indicators of faecal contamination hence the possible presence of enteric pathogens.

Klebsiella sp may cause severe bronchopneumonia (Itah 1997). Klebsiella and some strains of Enterobacter species have been implicated in acute and chronic diarrhoeal disease (Wilson et al, 1983).

Table 2: Incidence of bacteria isolated from the meat cuts and flies examined $(n=50$ each $)$

\begin{tabular}{|l|c|c|c|c|}
\hline Type of organism & $\begin{array}{c}\text { Meat } \\
\text { cut }\end{array}$ & $\%$ & Flies & $\%$ \\
\hline Escherichia coli & 20 & 40 & 23 & 46 \\
\hline Micrococcus roseus & 8 & 16 & 10 & 20 \\
\hline Staphylococcus aureus & 24 & 48 & 25 & 50 \\
\hline Staphylococcus epidermidis & 13 & 26 & 17 & 34 \\
\hline Bacillus subtilis & 7 & 14 & 11 & 22 \\
\hline Proteus sp & 6 & 12 & 7 & 14 \\
\hline Streptococcus sp & 7 & 14 & 10 & 20 \\
\hline Klebsiella sp & 6 & 12 & 11 & 22 \\
\hline Pseudomonas sp & 8 & 16 & 10 & 20 \\
\hline Bacillus cereus & 20 & 40 & 22 & 44 \\
\hline Bacillus sp & 20 & 40 & 20 & 40 \\
\hline Salmonella sp & 15 & 30 & 5 & 10 \\
\hline
\end{tabular}


Salmonella causes severe gastroenteritis among children and adult of all ages and is a serious zoonotic disease with a complex epidemiological cycle (Palmer and Row, 1986). Bacillus cereus has been implicated in food poisoning incidence (Itah and Opara, $1994 \mathrm{a}$ and b).

The high incidence of Staphylococcus in raw meat is indicative of unaccepted level of contamination and can give rise to enterotoxins, which do not alter the appearance of the food. Such contaminated meats may constitute serious public health hazard (Itah and Opara 1997).

Fungi isolated from both flies and meat included Aspergillus, Penicillin and Mucor species. They produce mycotoxins which have been implicated in aflatoxin related illnesses. Aspergillus sp and Penicillin sp have been reported to be capable of excreting toxic metabolites noted to be harmful to man and domestic animals (Talbot, 1978).

in conclusion, fresh meat sold in Uyo abattoir are contaminated by a wide variety of pathogenic bacteria and fungi with flies as their vectors. The predominance of food poisoning organisms like Staphylococcus aureus, and the occurrence of $E$. coli, Bacillus cereus, Streptococcus sp. and Klebsielle sp is indicative of gross contamination and constitute potential hazard to consumers and sellers. A critical reexamination of food sanitary quality and intensification of effective public enlightenment strategies are imperative to improve the keeping quality of meat.

\section{REFERENCES}

Awan, J. A., 1983, Elements of food borne disease. The Institute of management and Technology,

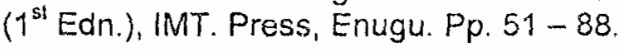

Cowan, S. T., 1985. Manual for identification of medical Bacteria. (2 ${ }^{\text {nd }}$ Edn.), Cambridge University Press, London. Pp. 40-76.

Cruickshank, R, Duguid, J. P., Mamion, B. P. and Swain, R. H. A., 1975. Medical microbiology (12 $2^{\text {th }}$ Edn.) Longman Group Ltd., London. pp. $200-241$.

Fawole, M. O. and Oso, B. A., 1988 Laboratory manual of microbiology. Spectrum Books Ltd. Sunshine House, Ibadan, Nigeria. P 27.

Frazier, W. C. and Westhoff, D. C., 1978. Food microbiology. Tata Mcgraw - Hill publishing company Ltd., New Delhi. Pp. $212-240$.

Greenberg, B. and Bornstein, A., 1973. Factors affecting the transmission of Salmonella by flies, Insect immunology, 2: $800-309$.

Holt, J. G., Krieg, N. R., Sneath, P. H. A., Stanley, J. T and Williams, S. T., 1994. Bergeys manual of determinative Bacteriology. $\left(9^{\text {th }} \quad\right.$ Edn.). Williams and Wilkins publishers Baltimore, $U$. S. A. $787 p$.
International Commission of microbiological specification for foods (ICMSF), 1980. Micro-organism anc Ecology of food. Univarsity of Toronto press, Toronto.

Itah, A. Y and Opara, A. A., 1994a. Enterotoxigenicity profile of Bacillus cereus strains isolated from canned foods in Calabar, Nigeria using the ligated rat ideal loop technique. Journal of medical laboratory Science, 4: $91-36$.

Itah, A. Y and Opara, A. A., 1994b. Prevalerice, characterization and antibiogram of Bacillus cereus strains isolated from canned foods sold in Calabar, Nigeria. Journal of medical laboratory sciences, 4: 87-90.

Itah, A. Y and Opara, A. A., 1997. Enterotoxin production by Staphylococcus aureus strains contaminating canned foods in Calabar, Nigeria. Journal of science, Engineering and Technology, 4(2): $740-750$.

Itah, A. Y., 1997. Incidence of Thermoduric psychotropic bacteria isolated from canned foods in South Eastern Nigeria. Nigerian Journal of microbiology. 11(1-2): $45-51$.

Itah, A. Y., 1998. Creating public awareness in environmental and public health education. The Nigerian situation. In communicating science, technology and mathematics. Olarewaju A. O (edition) Proc. $39^{\text {th }}$ Ann. Conf., Sci. Teachers Assoc Nig. (STAN), Osogbo, Osun State. Pp. $186-189$.

Palmer, S. R. and Rowe, B., 1986. Trends in Salmonella infection. PHLS Microbiology Digest. 3: $1-9$

Porke, K. S., 1971. Bacterial contamination of meat during transport from the butchery to home. Korean J. of Public Health, 6 (3): $1974-1979$.

Sabestine, A. A. and Aye, T., 1989. The carriage of enteric bacterial pathogen by Housefly. Journal Diarrhoea Res. 10: Pp. $81-84$.

Snedecor, G. W. and Cochran, W. G., 1978. Statistical methods $\left(6^{\text {th }}\right.$ edn.) lowa State University press, Ames, lowa, USA.

Talbot, P. H. B., 1978. Principles of fungal taxonomy, Macmillan Press Ltd., London. p. 274.

Wilson, G. S., Miles, A. A. and Parker, M. T., 1983. Trophey and Wilson's principles of Bacteriology, virology and Immunity $7^{\text {th }}$ Edition. Edward Arnold Publishers, London. 1: $231-234$. 